\title{
Sequence of rat RL/IF-1 encoding IKB $\beta$-like activity and comparison with related proteins containing notch-like repeats
}

Manorama Tewari, Kenneth L.Mohn ${ }^{1}$, Frank E.Yue ${ }^{1}$ and Rebecca Taub ${ }^{1 *}$

Department of Human Genetics and ${ }^{1}$ Howard Hughes Medical Institute, 475 CRB, University of Pennsylvania School of Medicine, Philadelphia, PA 19104-6145, USA

Previously, we identified an immediate-early gene, RL-14, rapidly induced in regenerating liver and mitogen-stimulated cells (1). Complete DNA sequence analysis of the full-length RL-14 clone corresponding to the $1.8 \mathrm{~kb}$ mRNA, showed that RL-14 encodes a 314 amino acid protein containing 5 notch-like repeats. RL-14, which we then designated RL/IF-1, regenerating liver inhibitory factor-1, is the rat homolog of human MAD-3 (2) and probably of chicken pp40 (3) which have IKB-like activity. IKB proteins are cytoplasmic inhibitors of p50/p65 NF-KB and Rel family transcription factors that mediate inhibition by binding to Rel and NF-KB subunits. Upon cellular stimulation, IKB is released from NF-KB and Rel which then can move to the nucleus and activate transcription $(4,5)$. RL/IF- 1 and MAD-3 share $80 \%$ nucleotide and $90 \%$ amino acid homology, and RL/IF-1 and chicken pp40 protein share $63 \%$ nucleotide and $70 \%$ amino acid identity, including some nucleotides in the $3^{\prime}$ untranslated region. We have demonstrated that RL/IF- 1 has IKB $\beta$-like activity in that it inhibits the DNA binding of NF-KB, c-Rel and RelB, and is likely to be identical to $\operatorname{IKB} \beta(6,7,8)$.

In data bank searches RL/IF-1 and MAD-3 have greatest homology with notch-like repeat proteins related to the NF-KB family of transcription factors. These include the repeat region of p105, the precursor to the p50 subunit of NF-KB $(9,10,11)$, and the precursor protein for $\mathrm{p} 49$ or $\mathrm{p} 50 \mathrm{~B}$, an NF-KB-like protein (12). Two other highly related proteins are BCL-3, a repeat protein found at the chromosomal translocation break point in B cell tumors (13) and Fem-1, a C. elegans protein involved in sex determination (14). The alignments of RL/IF-1 with this group of proteins (Fig. 1) indicate that not only the consensus sequences in the repeats are similar, but the order of highly similar repeats is conserved. Although there are only five true repeats in RL/IF-1, there is the beginning of a sixth repeat which shares homology with the corresponding repeat in the other proteins. Within the repeat regions the overall amino acid identity of
RL/IF-1 with p105 NF-KB, p49/p50B NF-KB, BCL-3, and Fem- 1 are $41 \%, 37 \%, 33 \%$ and $31 \%$, respectively. Additionally, like RL/IF-1, both p105 NF-KB, p49/p50B NF-KB have an acidic carboxy terminus of unknown function. These findings suggest that this group of repeat proteins are derived from a common ancestor, and may have similar IKB-related functions. Much less similar are ankyrin, notch and other repeat proteins with structural roles (15). However, like ankyrin, it is likely that notch-like repeats in the IKB proteins are involved in the dimerization of IKB with Rel family members.

\section{REFERENCES}

1. Mohn,K.L., Laz,T.M., Hsu,J.-C., Melby,A.E., Bravo,R. and Taub,R. (1991) Mol. Cell. Biol. 11, 381-390.

2. Haskill,S., Beg,A.A., Thompkins,S.M., Morris,J.S., Yurochko,A.D., Johannes,A.S., Móndal,K., Ralph,P. and Baldwin,A.S.,Jr (1991) Cell 65, $1281-1289$

3. Davis,N., Ghosh,S., Simmons,D.L., Tempst,P., Liou,H.C., Baltimore,D. and Bose,H.R.,Jr (1991) Science 253, 1268-1271.

4. Ghosh,S. and Baltimore,D. (1990) Nature 344, 678-682.

5. Lenardo,M.J. and Baltimore,D. (1989) Cell 58, 227-229.

6. Tewari,M., Dobrzanski,P., Mohn,K.L., Hsu,J.-C., Bravo,R. and Taub,R. (1991) Mol. Cell. Biol. Submitted.

7. Kerr,D.L., Inone,J., Nathan,D., Egenhard,L., Baeuerle,P.A., Bose,H.R.,Jr, and Verma,I.M. (1991) Genes and Development 5, 1464-1476.

8. Ryseck,R.-P., Bull,P., Takayima,M., Bours,V., Siebenlist,U., Dobrzanski,P. and Bravo,R. (1992) Mol. Cell. Biol. in press.

9. Kieran,M., Blank,V., Logeat,F., Vandekerckhove,J., Lottspeich,F., Bail,O.L., Urban,M.B., Kourilsky,P., Baeuerle,P.A. and Israel,A. (1990) Cell 62, 1007-1018.

10. Bours, V., Villalobos,J., Burd,P.R., Kelly,K. and Siebenlist,U. (1990) Nature 348, 76-80.

11. Ghosh,S., Gifford,A.M., Riviere,L.R., Tempst,P., Nolan,G.P. and Baltimore,D. (1990) Cell 62, 1015-1025.

12. Schmid,R.M., Perkins,N.D., Duckett,C.S., Andrews,P.C. and Nabel,G.J. (1991) Nature 352, 733-736.

13. Ohno,H., Takimoto,G. and McKeithan,T.W. (1990) Cell 60, 991-997.

14. Spence,A.M., Coulson,A. and Hodgkin,J. (1990) Cell 60, $981-990$.

15. Lux,S.E., John,K.M. and Bennett,V. (1990) Nature 344, 36-42.
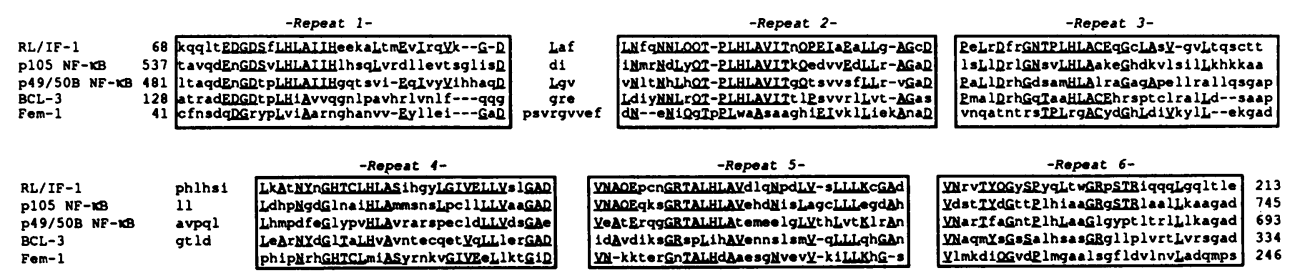

Alignment between notch-like repeat regions of RL/IF-1, p105 NF-KB, p49/p50b NF-KB, BCL-3 and c-Fem-1. Identities are capitalized and underlined, and notch-like repeat regions are indicated.

* To whom correspondence should be addressed 